\title{
INTERACTION OF I.V. DYNORPHIN A(1-13) WITH KAPPA AND MU AGONISTS IN A THERMAL ANTINOCICEPTION ASSAY IN RHESUS MONKEYS.
}

Butelman ER, France CP, Woods JH. Univ. of Michigan, Ann Arbor, MI 48109 and Louisiana State Univ. Medical Center, New Orleans, LA 70119, USA.

The agonist and antagonist effects of intravenously administered dynorphin A(1-13) (DYN) were characterized in the warm water $\left(50^{\circ}\right.$ and $\left.55^{\circ} \mathrm{C}\right)$ tail withdrawal assay of antinociception in rhesus monkeys $(\mathrm{n}=3)$. The peptide was effective in $50^{\circ}(0.01-3.2 \mathrm{mg} / \mathrm{kg})$, but was ineffective in $55^{\circ}$. The antinociceptive effect of DYN was blocked by quadazocine $(1.0 \mathrm{mg} / \mathrm{kg}$ ) and nor-binaltorphimine (norBNI, $3.2 \mathrm{mg} / \mathrm{kg}$ ); consistent with a kappa-opioid receptor mediated agonist effect of the peptide. Pretreatment with DYN antagonized the antinociceptive effects of just maximally effective (JME) doses of U50,488 $(1.8 \mathrm{mg} / \mathrm{kg})$ and $U 69,593(0.18 \mathrm{mg} / \mathrm{kg})$ in $55^{\circ}$; consistent with a low efficacy action of the peptide at the receptor activated by the two above kappa agonists. Interestingly, DYN $(3.2 \mathrm{mg} / \mathrm{kg}) \mathrm{did}$ not antagonize JME doses of other kappa agonists, such as bremazocine $(0.056 \mathrm{mg} / \mathrm{kg})$, CI-977 $(0.018 \mathrm{mg} / \mathrm{kg}$ ), and ethylketocyclazocine (EKC, $0.18 \mathrm{mg} / \mathrm{kg}$ ). Dynorphin also decreased the antinociceptive effects of the mu agonists fentanyl $(0.056 \mathrm{mg} / \mathrm{kg})$ and etonitazene $(0.0032 \mathrm{mg} / \mathrm{kg})$ in this assay. The above results are consistent with a low efficacy kappa-agonist effect of i.v. DYN in the present assay, and with the possibility that DYN A(1-13) may antagonize the antinociceptive effect of only a subset of kappa agonists, under these conditions.

Methodology: A warm water $\left(50^{\circ}\right.$ and $\left.55^{\circ}\right)$ tail withdrawal assay in rhesus monkeys has previously been used to characterize the pharmacology of opioid compounds $(1,2)$. Here we report on the characterization of the agonist and antagonist effects of i.v. DYN as determined in time course and cumulative dosing experiments. Agonist effects of DYN: DYN (0.01-3.2 $\mathrm{mg} / \mathrm{kg}$ ) was fully effective in $50^{\circ}(\mathrm{n}=3, \mathrm{~A} 50=0.4 \mathrm{mg} / \mathrm{kg})$ but was ineffective in $55^{\circ}$. The highest DYN doses also produced a behavioral syndrome which usually comprised a brief $(3 \mathrm{~min})$ period of facial flushing, followed by a more protracted (approximately $30 \mathrm{~min}$ ) period of sedation and muscle relaxation. The antinociceptive effects of $3.2 \mathrm{mg} / \mathrm{kg}$ DYN peaked between $30-60 \mathrm{~min}$ after administration. The agonist effects of DYN were antagonized by quadazocine $(1.0 \mathrm{mg} / \mathrm{kg})$ and nor-BNI $(3.2 \mathrm{mg} / \mathrm{kg})$. Antagonist effects of DYN: Under conditions when it was ineffective (i.e., in $\left.55^{\circ}\right)$, DYN (0.032-3.2 mg/kg) antagonized the antinociceptive effects of JME doses of U50,488 (1.8 mg/kg) (see Fig.) and U69,593 $(0.18 \mathrm{mg} / \mathrm{kg})$ in a surmountable and dose-dependent manner (not shown).

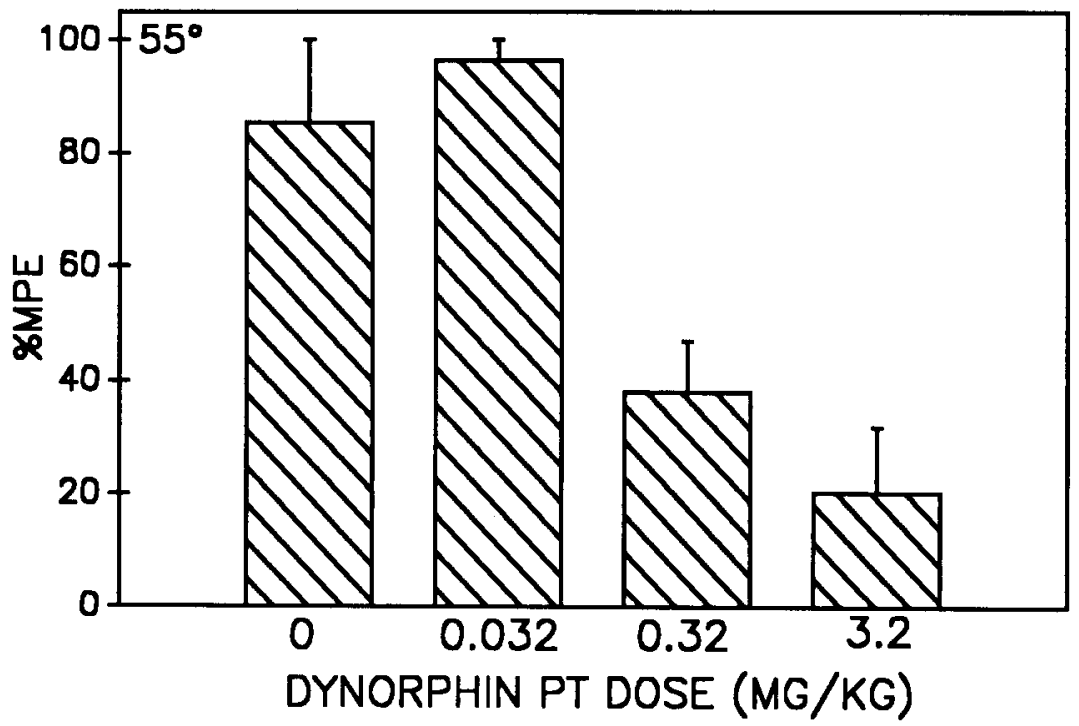

Figure. Antagonist effects $\left(55^{\circ}\right.$ water) of i.v. DYN administered $3 \mathrm{~min}$ before $1.8 \mathrm{mg} / \mathrm{kg}$ s.c. U50,488. The present values were obtained $45 \mathrm{~min}$ after U50,488, its time of peak effect. Abscissa: pretreatment (PT) DYN dose, ordinate: \% maximum possible effect (\%MPE, mean $+/-$ S.E., $n=3$ ). 
DYN (3.2 $\mathrm{mg} / \mathrm{kg}$ ) administered $3 \mathrm{~min}$ before U50,488 produced a $1 / 2 \mathrm{log}$ unit rightward shift in the U50,488 dose-effect curve in $55^{\circ}$. When DYN $(3.2 \mathrm{mg} / \mathrm{kg})$ was administered $120 \mathrm{~min}$ before U50,488, no antagonism was observed, suggesting that the duration of the agonist and antagonist effects of DYN were similar. Furthermore, non-antinociceptive DYN doses (e.g., $0.032 \mathrm{mg} / \mathrm{kg}$ ) were also devoid of antagonist effects against U50,488. Interestingly, DYN $(3.2 \mathrm{mg} / \mathrm{kg}) \mathrm{did}$ not antagonize the antinociceptive effects of JME doses of the kappa- opioid agonists bremazocine $(0.056 \mathrm{mg} / \mathrm{kg})$, CI$977(0.018 \mathrm{mg} / \mathrm{kg})$ or EKC $(0.18 \mathrm{mg} / \mathrm{kg})$ in $55^{\circ}$. DYN $(0.0032-3.2 \mathrm{mg} / \mathrm{kg})$ dose-dependently antagonized the antinociceptive effects of JME doses of the mu-opioid agonists fentanyl (0.056 $\mathrm{mg} / \mathrm{kg})$ and etonitazene $(0.0032 \mathrm{mg} / \mathrm{kg})$.

Discussion: DYN was effective in $50^{\circ}$ but not $55^{\circ}$ water in rhesus monkeys; the temperature dependency of the antinociceptive effects of DYN suggest that it may have limited efficacy, and that its antinociceptive effects were not secondary to an impairment in the subjects' ability to perform the required response (2). The fact that DYN was antagonized by a relatively high quadazocine dose (1.0 $\mathrm{mg} / \mathrm{kg}$ ) and by nor-BNI $(3.2 \mathrm{mg} / \mathrm{kg})$ is consistent with kappa-opioid mediation of the antinociceptive effects of DYN (1,3). If DYN was acting as a low efficacy kappa-agonist in the present preparation, it would be expected to antagonize kappa-receptor mediated effects under conditions in which it had no antinociceptive effect (e.g., in $55^{\circ}$ water, see reference 2). This was indeed the case, since DYN antagonized the antinociceptive effects of two kappa-opioid agonists (U50,488 and U69,593) in $55^{\circ}$ water. The time course and doses for the antagonist effects of DYN closely resembled those for the agonist effects of DYN in $50^{\circ}$ water, consistent with the possibility that they may both reflect the same mechanism. The fact that DYN $(3.2 \mathrm{mg} / \mathrm{kg})$ did not antagonize the effects of other kappa-agonists (bremazocine, CI-977, EKC) in $55^{\circ}$ water may be an indication that these agonists did not act through the same receptors as U50,488 and U69,593 in the present assay. This possibility is further supported by the fact that nor-BNI antagonized the antinociceptive effects of U50,488 and U69,593 (3) as well as those of DYN, but not those of bremazocine, CI-977, or EKC. DYN $(0.0032-3.2 \mathrm{mg} / \mathrm{kg})$ also antagonized the antinociceptive effects of the mu-agonists etonitazene and fentanyl, similar findings have previously been reported for the effects of i.c.v. DYN on morphine antinociception in mice (4). This further suggests that the lack of DYN antagonism of CI-977, bremazocine and EKC cannot be ascribed to the possibility that these compounds may have mu-agonist effects in this assay. The present findings suggest that DYN may have low efficacy effects through a subset of kappa-opioid receptors in the present assay.

Supported by USPHS Grant DA 00254.

\section{REFERENCES}

1. L.A. Dykstra, D.E. Gmerek, G. Winger, J.H. Woods (1987)

J. Pharmacol. Exp. Ther. 242, 421-427

2. E.A. Walker, E.R. Butelman, J.H. Woods (in press) J. Pharmacol. Exp. Ther.

3. E.R. Butelman, S.S. Negus, Y. Ai, B.R. De Costa, J.H. Woods (in press)

J. Pharmacol. Exp. Ther.

4. F.C. Tulunay, M.F. Jen, J.K. Chang, H.H. Loh, N.M.Lee (1981)

J. Pharmacol. Exp. Ther. 219, 296-298 